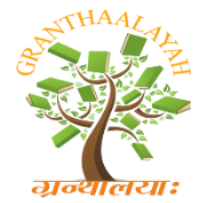

INTERNATIONAL JOURNAL OF RESEARCH GRANTHAALAYAH A knowledge Repository

Science

\title{
STUDY THE EFFECT OF EXCESSIVE SOIL CONTACT ON SOLES OF FEET IN DIFFERENT DEHA PRAKRUTI VOLUNTEERS WITH REFERENCE TO RUKSHADI VATA GUNA
}

\author{
Dr. Satish Babaso Patil *1 \\ ${ }^{* 1}$ Assistance Professor (Lecturer) - Kriya Sharir, Yashwant Ayurvedic College, P.G.T \& R.C \\ Kodoli, India
}

\begin{abstract}
Ayurveda is an ancient system of medicine documented and practiced in India since time immemorial. According to this system, an individual's Prakruti (basic constitution) to a large extent, determines predisposition and prognosis to diseases as well as therapy and lifestyle regime. Therefore, Prakruti pariksha plays an important role in examination of patient and diagnostic aspect hence can influences its prevention also. In Ayurveda excessive soil contact is main cause of padadari in explained under sushrut samhita. So, one needs to understand that there should be some correlation between excessive soil contact and padadari i.e cracked feet.
\end{abstract}

Keywords: Prakruti; Excessive Soil Contact; Padadari.

Cite This Article: Dr. Satish Babaso Patil. (2019). "STUDY THE EFFECT OF EXCESSIVE SOIL CONTACT ON SOLES OF FEET IN DIFFERENT DEHA PRAKRUTI VOLUNTEERS WITH REFERENCE TO RUKSHADI VATA GUNA." International Journal of Research Granthaalayah, 7(8), 342-357. https://doi.org/10.29121/granthaalayah.v7.i8.2019.683.

\section{Introduction}

Ayurveda has very practical approach towards the healthy human being. The aim of Ayurveda is to maintain healthy state of human body $\&$ cure disease, i.e. Ayurveda has two aspects, preventive aspect \& curative aspect.

The prakruti of person is defined by the characteristics they have, by constitution of doshas. Those exhibiting predominance of kapha, pitta, vata. Prakruti also refers to genetically determined physical and mental makeup. Even if we go by theory of genetics it is understood that an individual behavior or psyche is decided even before his birth. therefore, Prakruti pariksha plays an important role in examination of patient and diagnostic aspect hence can influences its prevention also.

The most fundamental and characteristic principle of Ayurveda are the tridoshas i.e the vata, pitta and the kapha. Vata dosha has specific characteristics like Ruksha, laghu, chala, Bahu, Shighra, Sheeta, Parusha, Vishad. The main sites of vata dosha are pakwashay, kati, sakthi, 
sparshanendriya. Vata dosha is vitiated due to dhatukhsya or margavrodha. This prakupit vayu travels through body and get accumulated, results in increase the guna of vata dosha abnormally at the site results in reduction of opposite gunas. Places which are empty will be the main site of accumulation of vata dosha.

This vitiated vata dosha shows effects on its main sites especially on skin which is present all over body such as dryness of skin, roughness of skin etc. As sole is part of skin similar effects can be seen on it. According to Ayurveda the disease in which Vata is increased producing fissure at sole region known as Padadari. Maharshi Sushrut and Vagbhat, Madhavnidan explained Padadari under group of disease known as "kshudrarogas".

In ayurveda excessive soil contact is main cause of padadari in explained under sushrut samhita. So one needs to understand that there should be some correlation between excessive soil contact and padadari i.e cracked feet.

\section{अनारोग्यमनायुष्यं चक्षुषोरूपघातकृत। पादाभ्यामनुपानभ्यां सदा चंक्रमणं नृणाम॥ (सु.चि.२४/७२)}

Due to not wearing proper shoes harm can occur to eyes and also foot \& leads to health problems. So people should use proper shoes while walking.

In other samhitas, this is mentioned under other diseases. In the initial stage of disease patient does not have any complaint. But as the disease progresses, it can lead to severe symptoms as acute pain, burning sensation, itching and even bleeding from cracks. Cracked soles can occur for a number of reasons, from lack of moisture to exposing footwear. Its noticed symptoms such as dry skin, thickening around your heels, or have cracked skin or heel pain, then knowing the causes one can understand the condition, and could prevent further relapses from happening.

Foot is the most neglected or least cared part of body resulting in certain day to day life. Knowing the importance of this part, Ayurvedic literature has precaution to take its maximum care. In India, most of the population lives in rural area i. e 70\%. Most of them work in the farms, in wet soil, on rough grounds, in water without foot wear, on rocks, and has to soil contact excessively which leads to cracked foot. Also, now a days, people have become more conscious about their appearance considering cracked foot as a cosmetic problem.

\subsection{Need of Study}

Some people can not take care of their health because of daily income source like workers, farmers, who have to walk excessively for the work with or without footwear. So, they may face problems like cracked feet, Padadari can be correlated with cracked feet or heel fissures.

Cracked feet (especially in the heel region) is a common foot problem for both men and women. It also affects the beauty of sole. Maintenance of normal health of feet without any costly treatment just by pathyapathya and knowing facts about it can help patient to avoid such complaints. 


\subsection{Aim}

- To Study the Effect of Excessive soil contact On Soles of Feet In

- Different Deha Prakruti Volunteers with Reference to Rukshadi Vata Guna.

\subsection{Objectives}

1) To study the detection of prakruti by standard prakruti proforma.

2) To study the effects of excessive soil contact on sole of feet.

3) To study the association between padadari and deha prakruti.

\section{Review of Literature}

All available ayurvedic literature were reviewed for the concept of prakruti, vata dosha and its guna, twak and pada, padadari and its hetus. All the available modern literatures were reviewed for the concept of skin, sole, Cracked soles, and its causes.

\subsection{Concept of Prakruti.}

According to Ayurveda the psychosomatic constitution is also known as Deha prakruti. Prakruti is formed by predominance of one, two, or all three doshas at the time of union of shukra and shonita in garbhashay. In ayurvedic texts four types of prakrutis are mentioned.

They are as follows - 1. Doshaj prakruti 2. Manas prakruti 3. Bhautik prakruti 4. Jatyadi prakruti. Aacharya Charak, Sushrut, Vagbhat, Sharangdhar, Bhela, Harita have mentioned the characteristics of different types of deha prakruti. The interpretation of prakruti in Charak Samhita is more systematic than other samhitas because he differentiated the prakruti on the basis of guna as well as physical characteristics as compared to psychological traits. So particular gunas are mentioned for particular prakruti which didn't mentioned for other prakruti eg. Vata prakruti person will have ruksha parusha guna because of which he has parush paani-paada. This guna is not found in any other prakrutis. In sushrut Samhita and Vagbhat the characteristics of prakruti are described in terms of nature of other animals and description of dreams, which are not described in Charak Samhita. Prakruti plays an important role in healthy as well as diseased person. By understanding the individual constitution of every individual, we know which food, exercise, drinks, habits are appropriate for maintaining their health.

\subsection{Concept of Rukshadi Guna of Vata Dosha}

Vata dosha is most important dosha among all doshas, because it is the one who helps in all types of movements in body right from blinking of eyelids till peristalsis. No movements are possible without vata dosha. This is possible because of its guna which are mentioned in laghutrayis as well as bruhatrayis. Different aacharyas mentioned different guna of vata dosha, some of them are Ruksha, Sheeta, Khara, Sukshma, Chala, Parusha, Vishada etc. because of these guna, the effects are seen on human body which makes every human individual different from one another. When it comes to prakruti of vata dosha persons, though everyone has vatapradhan prakruti but the proportion of vata dosha gunas varies. So the characteristics of individual changes. It is mentioned 
in Sushrut Samhita and Laghutrayi due to excessive walking there is presence of twak rukshata, sputan and ruja at the sole region and it is a cause of many diseases like Padadari, Mudhagarbha, Shwas, Kasa, Pradar, Vatavyadhis, Vatarakta, Mutrkrucha, Mutraghat ect. All these diseases caused because of vitiated of vata dosha predominantly.

\subsection{Concept of Twak and Pada/Feet-}

If we consider problems related to pada like Ruskhta, Kharata, Padasfutan, Ruja are of sole or pada, but it is part of skin. So it is important to study the twaka from different samhitas. As it is sthan (main site) of vata dosha so it has importance in sense of touch. Hence also known as sparshnendriya. It has seven layers mentioned by aacharya Vagbhat, aacharya Sushrut, aacharya arundatta. Whereas charak and Bhela as mentioned six layers of it. Likewise, other references were found in tika written on charak Samhita. Also the Anatomy and Physiology was found in B.D.Chaurasiya, Gray's anatomy, Grants Atlas of Anatomy.

\subsection{Concept of Padadari and Cracked Heels}

Padadari is considered as a kshudra rogas. It is not mentioned in Kshudra rogas in Charak Samhita, it can be correlated as one of the nanatmaj vyadhi because its symptoms and treatments matches with padadari. In sushrut Samhita, Madhavnidan, Bhavprakash, vangsen samhita it is mentioned under Kshudrarogas. For modern references articles and journals were studied. Its hetus, lakshans, samprapti, treatments were referred from laghutrayi. Its hetus like excessive walking was discussed briefly. Hetu of padadari is mentioned in following points,

\subsection{Contact with Soil}

1) Bare foot walking

2) Not cleaning the foot

3) Not using proper shoes or chapples

i) Bare foot walking: - As described in sutra not only be cause of excessive walking but due to bare foot walking padadari occurs. Due to bare foot walking or not properly covering the foot leads to the contact with soil leading to padadari.

ii) Not cleaning the foot: - (सु.चि. २४/६९)

After contact with soil daily cleaning of foot is very important. Due to cleaning the foot soil will not remain on foot. This helps in reducing the cracks on heel.

iii) Not using proper shoes or chappals-

Using properly covered shoes or chappals are necessary for avoiding contact with soil while walking.

\section{पादरोगहरं वृष्यं रक्षोघ्नं प्रीतिर्वधनम्। सुखप्रचारमोजस्य सदा पादत्रधारणम्॥ (सु.चि. २४/७१)}

Maharshi Sushrutacharya, has described importance of proper shoes or chappals for foot. 


\section{अनारोग्यमनायुष्यं चक्षुषोरूपघातकृत। \\ पादाभ्यामनुपानभ्यां सदा चंक्रमणं नृणाम॥(सु.चि.२४/७२)}

Due to not wearing proper shoes harm can occur to eyes and also foot \& leads to health problems. So people should use proper shoes while walking.

Padadari Samprapti (Excessive soil contact is main cause of Padadari) - Schematic Presentation

Vataprakopaka hetu sevana (Excessive soil contact)

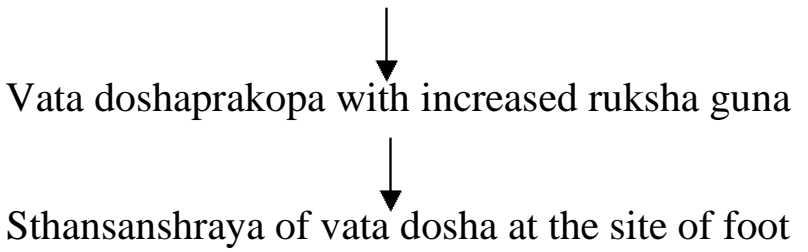

Padagata twak rukshata (dryness), darana (fissure) and ruja (pain)

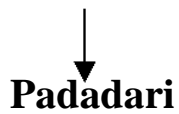

The vitiated vata produces cracks i.e. fissures at the feet with severe pain in the excessively dry feet of those who habitually do a lot of walking; the condition is diagnosed as Padadari.

\subsection{Relation of Prakruti and Sole}

In different deha prakruti, due to predominance of particular dosha, there is difference in characteristics of individual. So we can say that every part of human body shows difference like soles of vata prakruti are cracked as compare to pitta prakruti person and kapha prakruti person.

\section{Material and Methods}

\section{Literary Study Materials}

1) Brihataryi

- Charak samhita - Chakrapani tika.

- Sushruta samhita - Dalhan tika.

- Asthang Hridhaya - Hemadri tika.

2) Other ayurvedic texts.

3) Modern medical Books, Research Journals, Internet etc.

\section{Clinical Study Materials}

1) Standard prakruti proforma prakruti detection of 50 Vata Pradhan, 50 Pitta Pradhan and 50 Kapha Pradhan volunteers.

2) Equipment required for examination of cracked heels.eg torch, capillary Standardized Til taila etc.

3) CRF for sole examination. 
4) Self-generated questionnaire for assessment excessive walking on soles of feet.

5) Written consent of each volunteer.

6) Appropriate software for statistical analysis.

\section{Methodology}

\section{Sample Size}

- Sample size for present study is selected 150 volunteers having occupation farming.

- 50 volunteers of Vata pradhan prakruti,

- 50 volunteers of Pitta pradhan prakruti.

- 50 volunteers of Kapha pradhan prakruti.

\section{Inclusion Criteria}

- Age: 30-50 years.

- Sex: Both- male and female.

- 50 volunteers of each Vata pradhan, Pitta pradhan and Kapha Pradhan prakruti selected.

\section{Exclusion Criteria:}

- Subjects suffering from any $\mathrm{K} / \mathrm{C} / \mathrm{O}$ acute or major disorders Such as Diabetic foot, gangrenous foot.

- $\mathrm{K} / \mathrm{C} / \mathrm{O}$ acute or chronic medical or surgical illness.

\section{Observed Data Analysis Material}

Observed data was analyzed statistically with the help of graph pad.

\subsection{Methods}

Following is the plan which is followed during study.

\section{Prakruti Detection}

- Standard prakruti Proforma.

- The prakruti proforma which is collected from various ayurvedic texts.

- $\quad$ are used to identify the prakruti of volunteers.

\section{Enrolment of Volunteers}

- 50 volunteers of Vata pradhan prakruti, 50 volunteers of Pitta pradhan prakruti, 50 volunteers of Kapha pradhan prakruti in same season.

- Written consent of each volunteer is taken in Marathi/ English, which is given in annexure.

- Then they were studied with the help of Self-generated questionnaire for assessment effects of excessive walking on soles of feet $60 \%$ and above "Yes" criteria is considered as volunteer is having sol problem.

1) As per Ayurvedic and modern texts criteria case paper (CRF) was prepared and effects of excessive soil contact on soles were checked.

2) It is checked on the sole which shows maximum symptoms. For that parameters are divided into grades as follows. 


\begin{tabular}{|c|c|c|c|}
\hline \multicolumn{2}{|c|}{ Sr. NoSymptoms } & \multirow{2}{*}{$\begin{array}{l}\text { Description } \\
\mathrm{n} \text { No cracks }\end{array}$} & \multirow{2}{*}{$\begin{array}{l}\text { Grades } \\
0\end{array}$} \\
\hline 1 & Padasphutan & & \\
\hline & & $1-3$ cracks & 1 \\
\hline & & $4-5$ cracks & 2 \\
\hline & & More than 10 & 3 \\
\hline \multirow[t]{7}{*}{2} & Rukshata & Absent & 0 \\
\hline & & Small scales present & 1 \\
\hline & & Some larger scales & 2 \\
\hline & & present, possibly few & \\
\hline & & superficial cracks & \\
\hline & & Dominated by large & 3 \\
\hline & & scales, cracks present & \\
\hline \multirow[t]{2}{*}{3} & Kharata & Absent & 0 \\
\hline & & Present & 1 \\
\hline \multirow[t]{5}{*}{4} & Ruja & No pain & 0 \\
\hline & & Pain on digital pressure & 1 \\
\hline & & Pain while walking & 2 \\
\hline & & Constant pain or bleeding & $\mathrm{g} 3$ \\
\hline & & cracks & \\
\hline
\end{tabular}

Shoshan parikshan was observed by following grades-

- Volunteers were asked to wash his / her feet and dry them.0.5 mil til tel was taken.

- The sneh (tail) was gently applied on the soles of volunteer. Volunteer was in lying or sitting position in such a way that the sneh won't get wiped by other surfaces like cloths /floor.

- The time was noted at beginning as well as the time required to absorb the total amount of sneh by the sole.

Time taken by skin to absorb the sneha

Time taken by skinGrades

From 1 to $9-10$ mins 1

15-16 mins

\begin{tabular}{ll|}
\hline Above 16 mins & 3 \\
\hline
\end{tabular}

Depth of cracks was calculated according to following grades

\begin{tabular}{|l|l|l|}
\hline Nil & 0 & No cracks \\
\hline Mild & 1 & $\begin{array}{l}\text { Superficial } \\
\text { cracks }\end{array}$ \\
\hline Moderate 2 & Depth 1 mm to 3 \\
\hline & mm \\
\hline Severe & 3 & Depth $>3 \mathrm{~mm}$ \\
\hline
\end{tabular}




\section{Equipment's used for examination of soles were as follows}

- Capillary -Depth of the largest crack was measured with the help of capillary.

- Torch - Torch is used to view the total number as well as depth of cracks.

Total number of cracks were calculated by quadrants made for calculation easy.

- Watch- To note the timing of shoshan parikshan.

- Standard Til tel- Til tel was used for shoshan parikshan.

\section{Study Type: Observational study}

\section{Study Design}

Standard prakruti proforma was prepared to detect the prakruti of volunteer.

50 volunteers of each Vata, Pitta, Kapha pradhan prakruti were selected through inclusive criteria.

All volunteers were examined for the the soles examination-parameters like padasphutan, rukshata ,kharata, ruja at soles of feet.

During clinical examination Data was recorded.

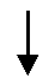

Recorded data was collected and Collected data was statistically analyzed.

The effect of excessive soil contact on soles of feet in different deha prakruti was evaluated.

\section{Duration: One year.}

Conclusion was drawn.

Statistical Analysis

Cross distribution of Prakruti group and Gender

\begin{tabular}{|l|l|l|l|l|l|l|l|l|l|}
\hline Groups & \multicolumn{3}{|l|}{ Kapha prakrutiPitta prakruti } & Vata prakruti & \multicolumn{2}{c|}{ Total } \\
\hline Sr.No. & Gender & Count & Percent & Count Percent & Count & Percent & Count Percent \\
\hline 1 & Male & 49 & $98.00 \%$ & 49 & $98.00 \%$ & 42 & $84.00 \%$ & 140 & $93.33 \%$ \\
\hline 2 & Female & 1 & $2.00 \%$ & 1 & $2.00 \%$ & 8 & $16.00 \%$ & 10 & $6.67 \%$ \\
\hline Total & 50 & $100.00 \%$ & 50 & $100.00 \%$ & 50 & $100.00 \%$ & 150 & $100.00 \%$ \\
\hline
\end{tabular}

In Kapha prakruti group, 49 patients (98\%) were male while 1 patient (2\%) was female. In Pitta prakruti group, 49 patients $(98 \%)$ were male while 1 patient $(2 \%)$ was female. In Vata prakruti group, 42 patients $(84 \%)$ were male while 8 volunteers $(16 \%)$ were female. 
Cross distribution of Prakruti group and Complaints with sole

\begin{tabular}{|c|c|c|c|c|c|c|c|c|c|}
\hline \multirow[b]{2}{*}{ Sr. } & \multirow{2}{*}{\begin{tabular}{|c|} 
Groups \\
$\begin{array}{c}\text { Complaints with } \\
\text { sole }\end{array}$ \\
\end{tabular}} & \multicolumn{3}{|c|}{ Kapha prakruti } & Pitta prakruti & \multicolumn{2}{|c|}{ Vata prakruti } & \multicolumn{2}{|r|}{ Total } \\
\hline & & Count & Percent & Count & & Coun & & Cou & \\
\hline 1 & Yes & 17 & $34.00 \%$ & 24 & $48.00 \%$ & 40 & $80.00 \%$ & 81 & \\
\hline & No & 33 & 66.0 & 26 & 52.0 & 10 & & 69 & $46.00 \%$ \\
\hline & Total & 50 & $100.00 \%$ & 50 & $100.00 \%$ & 50 & $100.00 \%$ & 150 & $100.00 \%$ \\
\hline
\end{tabular}

In Kapha prakruti group, 17 patients (34\%) were having complaints about sole while 33 patients $(66 \%)$ were not having sole complaints. In Pitta prakruti group, 24 patients $(48 \%)$ were having complaints about sole while26 patients (52\%) were not having sole complaints. In Vata prakruti group, 40 patients $(80 \%)$ were having complaints about sole while 10 patients $(20 \%)$ were not having sole complaints.

Cross distribution of Gender and Complaints with sole

\begin{tabular}{|l|l|l|l|l|l|l|l|}
\hline & \multicolumn{2}{|c|}{ Gender } & \multicolumn{1}{c|}{ Male } & \multicolumn{2}{c|}{ Female } & \multicolumn{2}{c|}{ Total } \\
\hline Sr. No. & Complaints with sole & Count & Percent & Count & Percent & Count & Percent \\
\hline 1 & Yes & 73 & $52.14 \%$ & 08 & $80.00 \%$ & 81 & $54.00 \%$ \\
\hline 2 & No & 67 & $47.86 \%$ & 02 & $20.00 \%$ & 69 & $46.00 \%$ \\
\hline & Total & 140 & $100.00 \%$ & 10 & $100.00 \%$ & 150 & $100.00 \%$ \\
\hline
\end{tabular}

- Out of 140 male patients, 73 patients (52\%) were seen with sole complaints

- while 67 patients $(48 \%)$ were without sole complaints.

- Out of 10 females, 8 patients $(80 \%)$ reported complaints regarding sole

- while 2 patients $(20 \%)$ were without sole complaints.

Distribution of volunteers according to Prakruti
\begin{tabular}{|l|l|l|l|}
\hline Sr. No.Prakruti & Count Percent \\
\hline 1 & Vata-Pitta & 22 & $14.67 \%$ \\
\hline 2 & Vata-Kapha 28 & $18.67 \%$ \\
\hline 3 & Pitta-Vata & 21 & $14.00 \%$ \\
\hline 4 & Pitta-Kapha 29 & $19.33 \%$ \\
\hline 5 & Kapha-Vata 22 & $14.67 \%$ \\
\hline 6 & Kapha-Pitta 28 & $18.67 \%$ \\
\hline & Total & 150 & $100.00 \%$ \\
\hline
\end{tabular}

22 patients (15\%) were of Vata-Pitta prakruti, 28 patients (19\%) were of Vata-Kapha prakruti, 21 patients (14\%) were of Pitta-Vata prakruti, 29 patients (19\%) were of Pitta-Kapha prakruti, 22 patients (15\%) were of Kapha -Vata prakruti while 28 patients (19\%) were with Kapha-Pitta prakruti.

\section{Statistical Methodology}

For various assessment parameters, equality of distribution among groups is tested using 'KruskalWallis test'. For post hoc analysis, Mann- Whitney U test is used with Bonferroni correction. 
The level of significance is kept at 0.05 throughout the analysis. Finding are presented with proper summary statistics - mean, median and S.D. In graphical representation, variability for mean is represented by S.E. as error bars.

Padasphutan Score

\begin{tabular}{|c|c|c|c|}
\hline Group & \multicolumn{3}{|c|}{ Median|MeanS.D. d.f.Kruskal - Wallis statistic|P-value } \\
\hline Vata prakruti & \begin{tabular}{|l|l|l|}
3 & 2.100 & 1.2822 \\
\end{tabular} & 49.068 & $<0.001$ \\
\hline Pitta prakruti & $0.880 \mid 1.062$ & & \\
\hline Kapha prakrutil & 0.2800 .573 & & \\
\hline
\end{tabular}

The distribution of padasphutan score was significantly different over 3 prakruti groups as observed by using Kruskal-Wallis test (P-value < 0.001$)$ at $5 \%$ level of significance.

Further, using Mann-Whitney $U$ test with Bonferroni correction as post-hoc test, there was significant difference $(\mathrm{P}$-value $=0.008$ ) between padasphutan score of Pitta prakruti group and Kapha prakruti group at 5\% level of signficance. Also, the padasphutan score for Vata prakruti group was significantly higher than of Pitta prakruti group (P-value $<0.001)$ and Kapha prakruti group (P-value $<0.001)$ at $5 \%$ level of significance.

Cross distribution of Padasputan and Prakruti

\begin{tabular}{|l|l|l|l|l|l|l|l|l|l|}
\hline & Groups & \multicolumn{2}{|c|}{ Kapha prakruti } & Pitta prakruti & Vata prakruti & \multicolumn{2}{c|}{ Total } \\
\hline \multicolumn{2}{|c|}{ Sr. No.Padasphutana } & Count & Percent & Count & Percent & Count & Percent & Count Percent \\
\hline 1 & 0 & 39 & $78.00 \%$ & 27 & $54.00 \%$ & 12 & $24.00 \%$ & 78 & $52.00 \%$ \\
\hline 2 & 1 & 8 & $16.00 \%$ & 6 & $12.00 \%$ & 2 & $4.00 \%$ & 16 & $10.67 \%$ \\
\hline 3 & 2 & 3 & $6.00 \%$ & 13 & $26.00 \%$ & 5 & $10.00 \%$ & 21 & $14.00 \%$ \\
\hline 4 & 3 & 0 & $0.00 \%$ & 4 & $8.00 \%$ & 31 & $62.00 \%$ & 35 & $23.33 \%$ \\
\hline & Total & 50 & $100.00 \%$ & 50 & $100.00 \%$ & 50 & $100.00 \%$ & 150 & $100.00 \%$ \\
\hline
\end{tabular}

Rukshata Score

\begin{tabular}{|c|c|c|c|c|}
\hline \multirow{2}{*}{\begin{tabular}{|l} 
Group \\
Vata prakruti \\
\end{tabular}} & \multicolumn{4}{|c|}{ MedianMeanS.D. d.f. Kruskal - Wallis statisticP-value } \\
\hline & 3 & \begin{tabular}{|l|l|l|}
2.240 & 1.2382 \\
\end{tabular} & 55.762 & $<0.001$ \\
\hline Pitta prakruti & 0 & $0.840 \mid 0.976$ & & \\
\hline Kapha prakru & & 0.3400 .626 & & \\
\hline
\end{tabular}

The distribution of rukshata score was significantly different over 3 prakruti groups as observed by using Kruskal-Wallis test $(\mathrm{P}$-value $<0.001)$ at $5 \%$ level of significance.

Further, using Mann-Whitney $U$ test with Bonferroni correction as post-hoc test, there was significant difference $(\mathrm{P}$-value $=0.027)$ between rukshata score of Pitta prakruti group and Kapha prakruti group at 5\% level of significance. Also, the rukshata score for Vata prakruti group was significantly higher than of Pitta prakruti group $(\mathrm{P}$-value $<0.001)$ and Kapha prakruti group $(\mathrm{P}$ value $<0.001)$ at $5 \%$ level of significance. 
Cross distribution of Rukshata and Prakruti

\begin{tabular}{|c|c|c|c|c|c|c|c|c|c|}
\hline \multirow{2}{*}{\multicolumn{2}{|c|}{\begin{tabular}{|l} 
Groups \\
Sr. No|R
\end{tabular}}} & \multicolumn{4}{|c|}{ Kapha prakruti|Pitta prakruti } & \multirow{2}{*}{\multicolumn{2}{|c|}{\begin{tabular}{|l} 
Vata prakruti \\
Count Percent \\
\end{tabular}}} & \multirow{2}{*}{\multicolumn{2}{|c|}{\begin{tabular}{|r|} 
Total \\
Count Percent
\end{tabular}}} \\
\hline & & $\mathrm{Cr}$ & it Percent & Co & tPercent & & & & \\
\hline 1 & 0 & 37 & $74.00 \%$ & 27 & $54.00 \%$ & 11 & $22.00 \%$ & 75 & $50.00 \%$ \\
\hline 2 & 1 & 9 & $18.00 \%$ & 5 & & 0 & 0.00 & 14 & 9.33 \\
\hline 3 & 2 & 4 & $8.00 \%$ & 17 & $34.00 \%$ & 5 & $10.00 \%$ & 26 & $17.33 \%$ \\
\hline 4 & 3 & 0 & $0.00 \%$ & 1 & $2.00 \%$ & 34 & $68.00 \%$ & 35 & $23.33 \%$ \\
\hline \multicolumn{2}{|c|}{ Total } & 50 & $100.00 \%$ & 50 & $100.00 \%$ & 50 & $100.00 \%$ & 150 & $100.00 \%$ \\
\hline
\end{tabular}

\begin{tabular}{|c|c|c|c|}
\hline \multicolumn{4}{|c|}{ Kharata Score } \\
\hline Group & Median|MeanS.D. & f.|Krusk & P-value \\
\hline Vata prakruti & \begin{tabular}{|l|l|l|}
1 & 0.620 & 0.4902 \\
\end{tabular} & 23.327 & $<0.001$ \\
\hline Pitta prakruti & 0.3200 .471 & & \\
\hline Kapha prakrutil & $0.160 \mid 0.370$ & & \\
\hline
\end{tabular}

The distribution of kharata score was significantly different over 3 prakruti groups as observed by using Kruskal-Wallis test $(\mathrm{P}$-value $<0.001)$ at $5 \%$ level of significance.

Further, using Mann-Whitney U test with Bonferroni correction as post-hoc test, there was no significant difference $(\mathrm{P}$-value $=0.189)$ between kharata score of Pitta prakruti group and Kapha prakruti group at $5 \%$ level of significance. Whereas, the kharata score for Vata prakruti group was significantly higher than of Pitta prakruti group $(\mathrm{P}$-value $=0.009)$ and Kapha prakruti group $(\mathrm{P}-$ value $<0.001)$ at $5 \%$ level of significance.

Cross distribution of kharata and prakruti

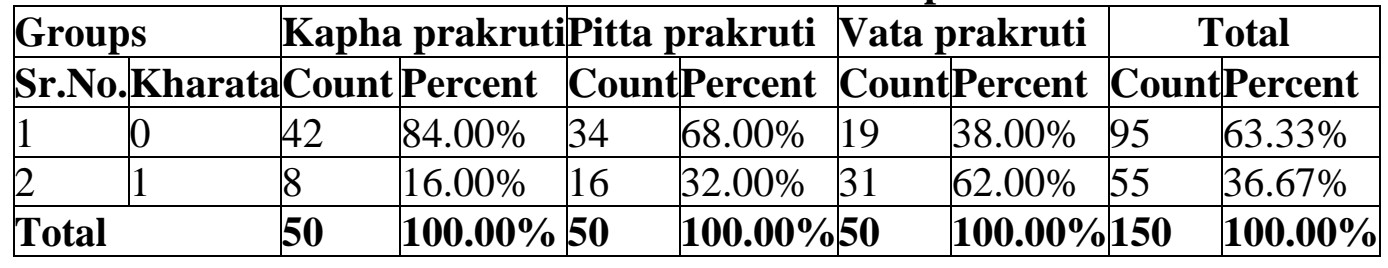

Ruja Score

\begin{tabular}{|l|l|l|l|l|l|l|}
\hline Group & Median & MeanS.D. & d.f. Kruskal - Wallis statistic P-value \\
\hline Vata prakruti & 3 & 2.600 & 1.161 & 2 & 39.602 & $<0.001$ \\
\hline Pitta prakruti & 1 & 1.660 & 0.917 & & & \\
\hline Kapha prakruti 1 & 1.240 & 0.555 & & & \\
\hline
\end{tabular}

The distribution of ruja score was significantly different over 3 prakruti groups as observed by using Kruskal-Wallis test $(\mathrm{P}$-value $<0.001)$ at $5 \%$ level of significance.

Further, using Mann-Whitney $\mathrm{U}$ test with Bonferroni correction as post-hoc test, there was significant difference $(\mathrm{P}$-value $=0.031)$ between ruja score of Pitta prakruti group and Kapha prakruti group at $5 \%$ level of significance. Whereas, the ruja score for Vata prakruti group was 
significantly higher than of Pitta prakruti group (P-value $<0.001)$ and Kapha prakruti group $(\mathrm{P}-$ value $<0.001$ ) at $5 \%$ level of significance.

Cross distribution of Prakruti and Ruja

\begin{tabular}{|c|c|c|c|c|c|c|c|c|c|}
\hline & \multicolumn{5}{|c|}{ Groups|Kapha prakruti|Pitta prakruti } & \multicolumn{2}{|c|}{ Vata prakruti } & \multicolumn{2}{|r|}{ Total } \\
\hline Sr.N & o.Ruja & Count & Percent & Cou & it|Percent & Cou & nt|Percent & Coun & it|Percent \\
\hline 1 & 0 & 41 & $82.00 \%$ & 30 & $60.00 \%$ & 13 & $26.00 \%$ & 84 & $56.00 \%$ \\
\hline 2 & 1 & 6 & $12.00 \%$ & 9 & $18.00 \%$ & 5 & $10.00 \%$ & 20 & $13.33 \%$ \\
\hline 3 & 2 & 3 & 6.0 & 9 & $0 \%$ & 20 & 40.1 & 32 & $33 \%$ \\
\hline 4 & 3 & 0 & $0.00 \%$ & 2 & $4.00 \%$ & 12 & $24.00 \%$ & 14 & $9.33 \%$ \\
\hline & Total & 50 & $100.00 \%$ & 50 & $100.00 \%$ & 60 & $100.00 \%$ & 150 & $100.00 \%$ \\
\hline
\end{tabular}

\section{Depth of Cracks Score}

\begin{tabular}{|c|c|c|c|}
\hline Group & Median|MeanS.D. d & f. Kruskal - Wallis statistic & P-value \\
\hline Vata prakruti & \begin{tabular}{|l|l|l|}
3 & 2.280 & 1.1962 \\
\end{tabular} & 60.591 & $<0.001$ \\
\hline Pitta prakruti & 0.8800 .960 & & \\
\hline Kapha prakrutic & 0.2860 .500 & & \\
\hline
\end{tabular}

The distribution of depth of cracks was significantly different over 3 prakruti groups as observed by using Kruskal-Wallis test $(\mathrm{P}-\mathrm{value}<0.001)$ at $5 \%$ level of significance.

Further, using Mann-Whitney $U$ test with Bonferroni correction as post-hoc test, there was significant difference $(\mathrm{P}$-value $=0.006)$ between depth of cracks score of Pitta prakruti group and Kapha prakruti group at $5 \%$ level of significance. Also, the depth of cracks score for Vata prakruti group was significantly higher than of Pitta prakruti group (P-value $<0.001)$ and Kapha prakruti group (P-value $<0.001)$ at $5 \%$ level of significance.

\section{Cross distribution of Prakruti and Depth of cracks}

\begin{tabular}{|c|c|c|c|c|c|c|c|c|c|}
\hline \multirow{2}{*}{$\begin{array}{l}\text { Group } \\
\text { Sr. No }\end{array}$} & \multirow{2}{*}{ Depth of Crack } & \multicolumn{4}{|c|}{ Kapha prakrutiPitta prakruti } & \multicolumn{2}{|c|}{ Vata prakruti } & \multicolumn{2}{|r|}{ Total } \\
\hline & & Count & Percent & Cou & int Percent & & unt Percent & Cour & ntPercent \\
\hline 1 & 0 & 37 & $74.00 \%$ & 26 & $52.00 \%$ & 10 & $20.00 \%$ & 73 & $48.67 \%$ \\
\hline 2 & 1 & 12 & $24.00 \%$ & 4 & $8.00 \%$ & 0 & $0.00 \%$ & 16 & $10.67 \%$ \\
\hline 3 & 2 & 1 & $2.00 \%$ & 20 & $40.00 \%$ & 6 & $12.00 \%$ & 27 & $18.00 \%$ \\
\hline 4 & 3 & 0 & $0.00 \%$ & 0 & $0.00 \%$ & 34 & $68.00 \%$ & 34 & $22.67 \%$ \\
\hline Total & & 50 & $100.00 \%$ & 650 & $100.00 \%$ & 750 & $100.00 \%$ & 150 & $100.00 \%$ \\
\hline
\end{tabular}

\section{Number of Cracks}

\begin{tabular}{|c|c|c|c|}
\hline Group & \multicolumn{3}{|c|}{ Median|MeanS.D. d.f.Kruskal - Wallis statisticP-value } \\
\hline Vata prakruti & \begin{tabular}{l|l|l|l|}
12 & 9.520 & 5.4562 \\
\end{tabular} & 56.002 & $<0.001$ \\
\hline Pitta prakruti & 2.1402 .140 & & \\
\hline Kapha prakrutit & $0.816 \mid 1.439$ & & \\
\hline
\end{tabular}

The distribution of number of cracks was significantly different over 3 prakruti groups as observed by using Kruskal-Wallis test $(\mathrm{P}$-value $<0.001)$ at $5 \%$ level of significance. 
Further, using Mann-Whitney $U$ test with Bonferroni correction as post-hoc test, there was significant difference $(\mathrm{P}$-value $=0.01)$ between number of cracks of Pitta prakruti group and Kapha prakruti group at 5\% level of significance. Also, the number of cracks for Vata prakruti group was significantly higher than of Pitta prakruti group (P-value $<0.001)$ and Kapha prakruti group $(\mathrm{P}-\mathrm{value}<0.001)$ at $5 \%$ level of significance.

Cross distribution of Prakruti and Shoshan parikshan

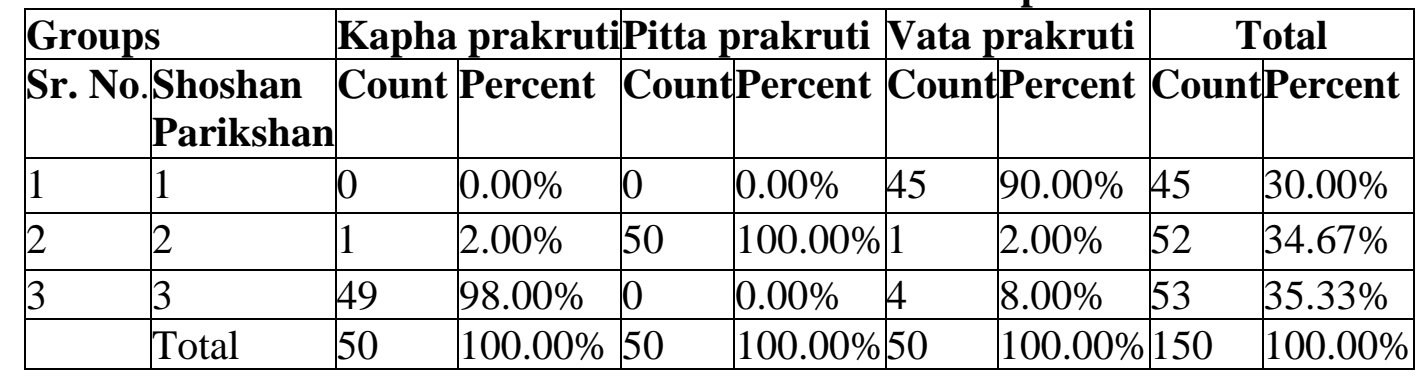

\section{Shoshan Parikshan Score}

\begin{tabular}{|l|l|l|l|l|l|l|}
\hline Group & Median & Mean & S.D. & d.f. & Kruskal - Wallis statistic P-value \\
\hline Vata prakruti & 1 & 1.180 & 0.560 & 2 & 124.83 & $<0.001$ \\
\hline Pitta prakruti & 2 & 2.000 & 0.000 & & \\
\hline Kapha prakruti 3 & 3.000 & 0.000 & & \\
\hline
\end{tabular}

The distribution of shoshan parikshan score was significantly different over 3 prakruti groups as observed by using Kruskal-Wallis test $(\mathrm{P}$-value $<0.001)$ at $5 \%$ level of significance.

Further, using Mann-Whitney $U$ test with Bonferroni correction as post-hoc test, there was significant difference $(\mathrm{P}$-value $<0.001)$ between shoshan parikshan score of Pitta prakruti group and Kapha prakruti group at 5\% level of significance. Also, the shoshan parikshan score for Vata prakruti group was significantly lower than of Pitta prakruti group (P-value $<0.001$ ) and Kapha prakruti group $(\mathrm{P}$-value $<0.001)$ at $5 \%$ level of significance.

\section{Discussion}

Discussions are divided in three parts:

1) Discussion on Review of Literature.

2) Discussion on material and methods.

3) Discussion on observations.

\subsection{Discussion on Review of Literature}

- All available ayurvedic literature were reviewed for the concept of prakruti, vata dosha and its guna, twak and pada, padadari and its hetus.

- All the available modern literatures were reviewed for the concept of skin, sole, Cracked soles, and its causes. 


\subsection{Discussion on Materials and Methods}

This conceptual part of this section contains mention of the literary part. The clinical part explains the detailed as follows.

- Preparation of prakruti proforma.

- Preparation of case paper as per Ayurvedic and modern criteria for the detection of sole problem- $60 \%$ and above "Yes" criteria is considered as volunteers are having sole complaints.

- In study 50 vata prakruti, 50 pitta prakruti and 50 kapha prakruti individuals were selected.

- Instruments like capillary and torch were use for detection of depth of cracks and number of total cracks.

- For shoshan parikshan til tail was used.

\subsection{Discussion on Observations}

\section{Prakruti}

- In Kapha prakruti group, 17 patients (34\%) were having complaints about sole while 33 patients $(66 \%)$ were not having sole complaints.

- In Pitta prakruti group, 24 patients (48\%) were having complaints about sole while 26 patients $(52 \%)$ were not having sole complaints.

- In Vata prakruti group, 40 patients $(80 \%)$ were having complaints about sole while 10 patients $(20 \%)$ were not having sole complaints.

- Maximum complaints related to sole and its intensity were found in group of vata prakruti volunteers. It may be due to guna of vata dosha is responsible for rukshata, kharata, ruja, and sputan.

\section{Gender}

Number of male patients were more than females. But the complaints regarding sole were more in intensity in females may be because females does all other household work along with the outside work so vataprakop is more in them.

\section{Number of Cracks}

Number of cracks were seen more in vata prakruti individual may be due to rukshadi vata guna. Pitta prakruti shown less number of cracks than vata prakruti because pitta has sasneha guna in it. Kapha prakruti individuals were having least number of cracks may be due to snighda guna present in it.

\section{Depth of Cracks}

Depth of cracks were highest in vata Pradhan prakruti may be because of parush guna present in vata dosha. Due to vata guna like ruksha, khara, parusha and vishada guna etc the skin of vata prakruti people shows more padasputan than pitta and kapha prakruti.

\section{Rukshata}

Hence we can say that rukshta is seen more in vata Pradhan volunteers compared to pitta and kapha. 


\section{Kharata}

The roughness was seen more in vata Pradhan prakruti may be because of khara guna of vata dosha present in it.

\section{Ruja}

The pain was seen more in Vata Pradhan prakruti may be as mentioned in Samhita there is no pain without Vata.

\subsection{Discussion on Overall Analysis}

For assessing relation between prakruti and sole complaints above mentioned subjective and objective parameters were considered. For this total summated score of all lakshanas are considered as volunteers are suffering from sole problem. And then this scores of three prakruti were compared.

Summated score of sole problem score was more in vata Pradhan prakrutis which was significantly higher than pitta prakruti and kapha prakruti. Also, summated score of pitta prakruti was significantly higher than kapha prakruti.

\section{Conclusion}

At the end of study, conclusions are drawn on the basis of the observations noted, results obtained and discussed with experts these are as follows:

- The vata dosha guna are responsible for Padasputan, Rukshata, Kharata, Ruja.

- Padasputan, Rukshata, Ruja are found in symptoms Padadari.

- Excessive soil contact is a cause of sole complaints in volunteers of all Prakrutis.

$>$ Excessive soil contact causes Padasputan, Kharata, Rukshata, Ruja at soles of feet i.e Padadari.

> Padasputan was seen significantly of higher grade ( $\mathrm{p}<0.001)$ in Vata Pradhan prakruti, moderate in Pitta pradhan Prakruti, least in Kapha pradhan prakruti at 5\% level of significance.

$>$ Rukshta was seen significanty of higher grade $(\mathrm{p}<0.001)$ in vata Pradhan prakruti, moderate in Pitta prakruti, least in Kapha Pradhan prakruti at 5\% level of significance.

$>$ Kharata was seen significanty of higher grade ( $\mathrm{p}<0.001)$ in vata Pradhan prakruti, moderate in Pitta prakruti, least in Kapha Pradhan prakruti at 5\% level of significance.

$>$ Ruja was seen significanty of higher grade $(\mathrm{p}<0.001)$ in vata Pradhan prakruti, moderate in Pitta prakruti, least in Kapha Pradhan prakruti at 5\% level of significance.

- Effect of Excessive soil contact was seen maximum in Vata pradhan prakruti, moderate in Pitta Pradhan prakruti and least in Kapha pradhan prakruti.

- So, Prakruti and Excessive soil contact both affects grades of symptoms of Padasputan, Rukshata, kharata, Ruja.

\section{References}

[1] Dr. Vidyadhar Shukla and Ravidatta Tripathi, Charak Samhita Chaukhambha Sanskrit Pratisthan, 2010, volume 1. 
[2] Dr. Shreemati Shailaja Shreevastava, Sharangdhar Samhita, Chaukhambha Orientalia, 2016, Purvakhanda.

[3] Dr. Ganesh Krushna Gadre, Astang Rhruday, Chaukhambha Surbharti Prakashan, 2018.

[4] Dr. Vidyadhar Shukla and Ravidatta Tripathi, Charak Samhita, Chaukhambha Sanskrit Pratisthanedition ,2010, volume 2.

[5] Proff. Yadunandana Upadhyaya, Madhav Nidan, Chaukhambha Prakashan, Vol.2.

[6] Dr. Shrikanth Murthy,Sushrut Smhita, Chaukhambha Publications, 2010 vol.1.

[7] Dr. Priyawat Sharma, Sushrut Samhita Dalhan tika, Chaukhambha Publications, 2 vol.1.

[8] Dr. Rajaradhakantdev Bahadur, Shabdakalpadrum, Chaukhambha Sanskrit Series.

[9] Dr. Ganesh Krushna Gadre, Sartha Vaghbhat, Chaukhambha Surbharati Prakashan, 2018.

[10] Rasavaisheshik sutra 1/16.

[11] Vaidya. Yadavji Trikmaji, Sushrut Samhita, Chaukhambha Sanskrit sansthan, 2010 vol.1.

[12] Dr. Jyotrmitra Aacharya, edited by Shivprasad Sharma, Astang Sangraha, Chaukhambha Sanskrit series office,2012, Purvardha.

[13] Dr. Hari Sadashiv Shastri Paradkar,Astang Rhruday- Arundatta teeka, chaukhambha surbharti prakashan Varanasi.

[14] Dr. Indradev Tripathi and Dayashankar Tripathi, Yogaratnakar Chaukhambha Krushnadas Academy Varanasi.

[15] Dr. Shreemati Shailaja Shreevastava, Sharangdhar Samhita, Chaukhambha Orientalia, 2016, Purvakhanda.

[16] Shree Abhay Katyayan, Bhel Samhita, Chaukhambha Surbharti Prakashan, 2009, Vimansthan.

[17] Pandit Hargovind Shastri, Amarkosha, Chaukhambha Sanskrit Pratisthan, 2008.

[18] K. Sembulingum and Prema Sembulingum, Essentials of Medical Physiology, Jaypee The Health Science Publishers.

[19] Dr. Vijaya Joshi and Dr. Sadhana Joshi- Mundhurwar, Physiology, Reed Elsevier India Private Limited,2011, 7/206-207.

[20] Dr. Krushna Garg and others, BD Chaurasia's Human Anatomy, CBS Publications and Distributors pvt, 2015, chap-10, page- 123-126.

[21] Anne M.R. Agur \& Arthur. P. Dalley, Grant's Atlas of Anatomy, Wolters Kluver India Pvt Ltd,12 th edition.

[22] Internet sources.

*Corresponding author.

E-mail address: anusatish37@ gmail.com 